YAK 327

ББK66.4(0)

DOI 10.22394/1682-2358-2021-6-38-51

Hagbbin Mobsen, postgraduate student of the Political Science and International Relations Department, Astrakhan State University

\section{MODERN EASTERN STRATEGY OF IRAN'S INTEGRATION PROCESSES: PROBLEMS AND PROSPECTS}

Foreign policies of the Russian Federation and the Islamic Republic of Iran are analyzed. Russia's foreign policy, based on the Eurasianism concept and aimed at the building-up a multipolar world with different centers of power is considered. Foreign policy positions and regional perspectives of the Islamic Republic of Iran are studied.

Key words and word-combinations: regional integration, Asia, Caspian region, Iran, "Look to the East", Russia, Eurasianism, anti-Atlanticism, China, multipolar world, American hegemony.
Хагбин Мохсен, аспирант кафедрь политологии и международньгх отношений Астраханского государственного университета (email: bagbin@asu.edu.ru)

\section{СОВРЕМЕННАЯ ВОСТОЧНАЯ СТРАТЕГИЯ ИНТЕГРАЦИОННЫХ ПРОЦЕССОВ ИРАНА: ПРОБАЕМЫ И ПЕРСПЕКТИВЫ}

Аннотация. Анализируется внешняя политика Российской Федерации и Исламской Республики Иран. Рассматривается внешняя политика России, исходящая из евразийской концепции и направленная на формирование многополярного мира с различными центрами силы. Изучаются внешнеполитические позиции и региональные перспективы Исламской Республики Иран.

Ключевые слова и словосочетания: региональная интеграция, Азия, Каспийский регион, Иран, «Взгляд на Восток», Россия, евразийство, антиатлантизм, Китай, многополярный мир, американская гегемония.

$\prod$ риоритеты внешней политики кажАого государства устанавииваются в рамках Аолгосрочной стратегии. Такие приоритеты обычно определяются в соответствии с условиями и тенденциями развития страны, а также с учетом возможности Аостижения цемей и на основе предполагаемых фактов. Серьезные изменения на межкународной арене делают неизбежным пересмотр и, возможно, переосмысление мюбым ак- 
тором своих внешнеполитических подходов и приоритетов. Подобные процессы наблюдаются в каждой динамично развивающейся стране. Исламская Республика Иран не является в этом плане исключением.

Ocoбое внимание Ирана к Востоку и укрепление отношений с такими странами, как Китай и Россия в рамках стратегического объединения в последние годы, вызвало реакцию со стороны как внутриполитических кругов Ирана, так и международных экспертов. Несомненно, множество региональных и международных факторов явилось причиной направленности ориентации Ирана на Восток.

Аля глубокого понимания внешней политики Ирана следует обратить внимание главным образом на официальное мнение Верховного мидера Иранской револющии, потому что он, без сомнения, играет фундаментальную и ключевую роль в определении общей политики управления иранским государственным аппаратом. Аидер Исламской революции Ирана аятома Хаменеи в своем выступцении от 18 февраля 2018 г. заявил: "ОАним из приоритетов сегодняшнего дня во внешней политике явцяется предпочтение Востока Западу, соседей дальним странам, народов и стран, имеющих с нами нечто общее, Аругим» [1]. Эти слова можно рассматривать в качестве ключевого тезиса в стратегии иранского Аипломатического аппарата. Но такой подход не означает отриџания Запада и безразцичия по отношению к нему, потому что в иранском документе под названием «Санаде чешмандазе джомхурие эсмамие» Иран дар офоке 1404 г. по иранскому календарю (2025 г.) [2] (далее - «Аокумент о перспективах 1404 г.»), на котором акцентирует внимание мидер Исламской революџии, «конструктивное взаимодействие с миром» упомянуто в качестве основы внешней политики Ирана.

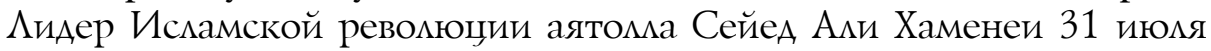
2020 г. выступиц с телеобрашением к иранскому народу по случаю праздника жертвоприношения ИА аль-ААха: «Мы можем и производить внутри и сделать так, чтобы многочисленные всевозможные научные, экономические и прочие возможности бурлили изнутри, а также можем работать на международной арене, в мире. У нас есть хорошие Арузья, мы можем работать с этими Арузьями. <... > У нас в мире есть эффективные Арузья... мы максимально воспользуемся, дай Бог, возможностями наших Арузей» [3] .

Безусловно, применение слова «Арузья» в разгар визита министра иностранных дел Ирана в Китай дмя проведения переговоров по закАючению 25-летнего стратегического соглашения с этой страной, его визит в Россию и переговоры о продлении 20-летнего соглашения с Россией, равно как и передача секретного послания Президента Исмамской Респубцики Иран Президенту России В.В. Путину подтверж- 
Аают, что иранское руководство положкительно оџенивает упомянутые отношения, и во внешней политике страны наметилась четкая тенденция на Восток. К тому же в феврале 2021 г., после прихода Аж. Байдена к власти в США, спикер парламента Исламской Республики Иран Калибаф прибыл в Москву, чтобы передать послание Верховного мидера Исламской револющии Ирана Президенту России. Складывается впечатление, что в данном послании мидер Исламской Республики Иран желал подчеркнуть прочность и неразрывность стратегических отношений межау Ираном и Россией [4]. Как стало известно, ответный шаг не заставил себя долго ждать: А.С. Ажагарян, посол Российской Федерации в Иране, передал послание Президента В.В. Путина для аятомлы А. Хаменеи на встрече с его советником и отметиц, что обе страны стремятся к наращиванию сотрудничества в различных сферах [5]. Отметим, что расширение диалога между государствами выражается не только в укрепиении торгово-экономических и политических связей, но имеет реальное выражение и в военной сфере: в феврале начались совместные военно-морские учения России и Ирана «Объединенный пояс безопасности 2021». Примечательно, что подобные учения впервые были проведены в 2019 г. [6], а в 2021 г. ужке были включены в календарь мероприятий стран-участниц. Более того, Китай принимал участие в указанных учениях ранее. В 2021 г. Индия также анонсироваяа свое участие [7].

Важжность политики ориентации на Восток после Исламской революции была обусловлена несколькими факторами, среди которых отмечают нежелание Ирана принять существующий международный порядок. Страна бросила вызов однополярному миру, взяв на вооружение принџипы и ценности Исламской революџии. Фактически после распада Советского Союза и еще большего укрепления позиций Соединенных Штатов Америки Иран был вынужден перейти к установлению взаимоотношений и взаимодействию со странами, которые, хотя и до распада Советского Союза находились в стороне Востока, после него остались недовольны международным порядком, основанным на гегемонизме США. Этот вопрос, в свою очередь, служил причиной формирования ориентации Ирана на Восток [8, с. 117].

Наряду с международными факторами региональная экономическая и политическая ситуация также стимулироваца внимание Ирана к Востоку. Самобытная изоляџия Исламской Республики на Ближнем Востоке [9, с. 56] и высокая активность великих держав в регионе Центральной Азии [10, с. 12] уничтожили преАпосылки Аля установмения всестороннего сотрудничества Ирана со странами Азиатского региона. На этой же основе азиатская интеграция могла быть прикрытием Амя восстановления идентичности и устранения нежемательной изоляџии 
Ирана в альянсе с более сильными партнерами региона [8, с. 117]. Перечисленные факторы, учитывая характер политической системы в Иране, показали, что политика ориентации на Восток имела цогическое и неявное оправдание.

Естественно, что внутри Ирана среди политиков, общественности и исследователей в области межкдународных отношений существуют разные взгляды и мнения о политике ориентации на Восток.

Сторонники политики, направленной на Восток, полагают, что ориентация Ирана на Восток и его союз с сильными азиатскими странами может послужить его наџиональным интересам и решить проблему отсутствия стратегического союзника [11]. Иранский исследователь Сакафи Амери считает, что ориентация на Восток - стратегическое мышмение, которое выходит за рамки расширения экономических связей и делает упор на политические и дипломатические отношения дия усиления сотрудничества в области безопасности и обороны с целью сбалансировать положкение Ирана в мире $[12$, с. 189; 13]. На самом деле среди кичностей, которые определяют внешнюю политику Ирана, всегда существовала такая идея, что для сбалансирования отношений с Западом необходимо приложить больше усилий аля сотрудничества с Востоком. Иными словами, сотрудничество с Востоком как противовес Западу всегда присутствовало в стратегическом мышиении иранской политической эмиты. В целом сторонники политики, ориентированной на Восток, полагают, что Исламской Республике Иран цегче наладить сотрудничество и создавать коалиции с Китаем, Россией, Индией, Малайзией и другими азиатскими странами, нежкели с западными игроками в сияу своей принадмежности к восточной цивилизаџии и присущих ей общих культурных, исторических и самобытных особенностей [14, с. 105-110].

Тяготение Ирана к Востоку, особенно в отношении Китая и России, вызвало у Аругих иранцев беспокойство за результаты переговоров Исламской Республики с прикаспийскими государствами по поводу Аоли сторон в Каспийском море. Эта озабоченность настолько была велика, что бывший Президент Ирана Махмуд Ахмадинежкад на встрече со своими сторонниками возразил: «Хотят подписать новый 25-цетний контракт с одной иностранной страной, и никто об этом не знает», хотя следует признать, что именно во времена Ахмадинежада ориентация внешнепоцитического аппарата на Восток стала стратегическим подходом. Исламская Республика пошиа на большие уступки восточным державам ради противостояния Западу из-за своих ядерных, ракетных и региональных программ и теперь может заплатить за это большую цену России и Китаю по мере усияения давления Соединенных Штатов Америки [15] .

Возможно, главная проблема выбранного внешнеполитического кур- 
са заключается в отсутствии консенсуса среди официальных миц относительно принципов, допущений и характера этого подхода. В мюбом случае, области, на которые наџелена указанная стратегия государства, вкАючают Восточную Азию (с такими ключевыми игроками, как Китай, Япония и Южная Корея), Южную Азию (с такими ключевыми игроками, как Индия и Пакистан), Юго-Восточную Азию (с такими кАючевыми игроками, как Малайзия) и Россию. Страны этих регионов вместе образоваци комплексную восточную цивилизацию, а в настоящее время возрождаются и консолидируются, по мнению некоторых аналитиков. Япония и Южная Корея из-за их преАанности США и полного растворения в западной культуре и миберальном капитализме не особенно вписываются в восточную цивилизацию и в значительной степени выходят за рамки рассматриваемых процессов. Таким образом, политика ориентации на Восток может быть основана на четырех столпах: России, Китае, Индии и Малайзии. Малайзия может стать ярким примером для развития Ирана. Она известна как независимая и развитая мусульманская страна, добившаяся больших успехов в области экономического развития за счет внеАрения эффективных моделей развития. Под ориентацией на Восток следует, по нашему мнению, подразумевать взгляд географический с акцентом на участников Шанхайской организаџии сотрудничества, хотя ее участники, такие как Россия, могут не обязательно находиться на Востоке, но несут своего рода восточную и азиатскую идентичность. Россия, Китай и Индия явцяются крупными игроками на региональной и международной аренах, в последние годы они развивались быстрыми темпами и набрали силу. Эти страны обцадают высоким потенџиалом для содействия в обеспечении интересов и национальной безопасности Исламской Респубцики Иран [14, с. 104] . Среди этих четырех стратегических столпов Востока Россия и Китай занимают особое место во внешней политике Ирана.

Стратегия «ВзгляА на Восток» не новая тема и по-разному проявцяма себя в различные периоды. При правительстве Хашеми Рафсанджани, когда возникли пробцемы и ограничения в отношениях с Западом, а также появицась необходимость восстановмения экономики страны и устранения ущерба, нанесенного войной с Ираком, Иран рассматривал возможность сотрудничества с Индией, Россией, Китаем в рамках альянса так называемого «стратегического союза». Стратегический поАход в тот период, по-видимому, быц основан на предположении, что Ирану нужны союзники в послереволюџионный период, чтобы иметь возможность противостоять враждебной политике США. В этом же направлении Хашеми Рафсанджани во время своего визита в Индию в 1996 г. удемял большое внимание укреплению отношений Ирана с сильными азиатскими странами $[14$, с. 110$]$. 
ОАнако Ирану не удалось найти себе стратегического союзника. Кажкется, что оАной из основных причин, по которым Россия, Китай и Индия не приветствовали план стратегического союза с Ираном, казалось, было то, что главной целью этого плана было создание блока против США, в то время как эти страны проводици политику воздержания от конфронтации, направленную на расширение отношений с Вашингтоном [13, с. 75-76].

Правительство Сейеда Мохаммада Хатами (1997-2005) также было заинтересовано работать в тесном сотрудничестве с Западом, но не упускало из виду Восток и Азию. В его периоА Иран, с одной стороны, подчеркивал свою этническую, языковую и религиозную общность со странами Центральной Азии и Кавказа, а с Аругой - расширял отношения с Россией. Китай как один из наиболее крупных игроков Востока тожке интересовал правительство Хатами. Визит Президента ИРИ в Китай в июне 2000 г. стал поворотным моментом в ирано-китайских отношениях. Сотрудничество в сферах экономики, энергетики и обороны явимось одной из важнейших повесток обсуждения Амя разговора межАу Авумя мидерами.

Со Аня вступления Ахмадинежада в Аолжность взгляд внешнеполитического аппарата на Восток, видимо, стал более серьезным и стратегическим, возросли решимость и желание офиџиальных киџ объединиться и сформировать союзы с восточными игроками. Аействительно, заметные успехи Востока в экономическом развитии в послеАние десятилетия и в то же время недовольство Ирана в отношении стран Запада, особенно на фоне кризиса ядерной программы, подогревали эти настроения. Признаки политики взаимодействия с Востоком можно было заметить в выступлениях и действиях офиџиальных миџ правительства девятого созыва Исламской Республики. Например, Ахмадинежад подчеркнул на 15-й сессии Совета министров Организации экономического сотрудничества: «Исламская Республика Иран, отдавая приоритет региональной повестке дня в межаународных отношениях и веря в необходимость сбалансировать свои внешние связи, что потребует усияения ориентации на Восток, готова искренне сотрудничать с Аругими странами региона в областях широкого и полезного экономического сотрудничества, установмения мира и безопасности в регионе» [13, с. 80]. В рамках стратегии «ВзгляА на Восток» правительство Ахмадинежада уделяло особое внимание углубцению отношений с тремя влиятельными игроками в регионе, а именно Китаем, Россией и Индией, а также было заинтересовано в использовании их возможностей дмя обеспечения национальных интересов и безопасности страны. ОАним из эффективных инструментов в этой области служит Шанхайская организаџия сотрудничества.

Среди предпосылок формирования стратегии «ВзгляА на Восток» во 
внешней политике Ирана можно выделить следующие: требования к реализации Аокумента о перспективах 1404 г., о перспективах развития страны; ненадежкность в отношениях с Западом, особенно в разрешении ядерного дела; увеличение мощи Востока за счет значительных экономических преобразований и развития передовых технологий $[14$, c. 106-108]. Фактически то, что в Иране рассматривается как стратегия «ВзгляА на Восток», имеет общее с политикой России в националистической славянской, евразийской и антиатлантической сферах. Эти течения в России также приветствуют независимость действий правительств, таких как Иран, опасающихся однополярной международной системы, основанной на гегемонии США и их оАносторонне направленной политики в межАународных вопросах [12, с. 189].

В иранской стратегии «ВзгляА на Восток» слеАует обратить внимание на этот регион в трех аспектах: политическом, обеспечении безопасности и экономическом. В политическом аспекте вес этого региона увеличивается с каждым днем, и Ирану следует более серьезно взаимодействовать с правительствами стран этого региона. В области безопасности региону угрожает международное вмешательство в борьбу местных государств с терроризмом. Иран имеет значительный опыт в указанной сфере и может эффективно работать в таких учреждениях, как ШОС. Во внешней политике Ирану следует также уделять приоритетное внимание Ближнему Востоку, больше взаимодействовать с правительствами России, Китая, Индии, Турџии и Аругих восточных стран, а также стать участником крупных региональных организаций дмя решения региональных проблем. Вступцение в Шанхайскую организацию сотрудничества может стать важным шагом дмя Аостижения этих цемей [16, с. 184-197].

В экономическом аспекте Организация экономического сотрудничества (ОЭС) - это важный шаг к активизации совместной Аеятельности с соседними странами. Со времени создания Аанной организаџии транспорт и коммуникации были приоритетными ее направлениями, и их важность возрастала с каждым днем. ОЭС ставила на повестку Аня реализацию проектов и программ Аля физического соединения стран-участников Аруг с Аругом и выхода на рынки за пределами региона через существующую транспортную инфраструктуру. ОАной из особенностей организации явцяется то, что она соединяет четыре региона: Южную Азию, Персидский залив, Центральную Азию и Кавказ. Сотрудничество ОЭС и Евразийского экономического союза, а также Шанхайской организаџии сотрудничества можно рассматривать как важную возможность Аля регионализации на Востоке [17, с. 27] .

Географическое расположение Ирана наряду с той ролью, которую он взял на себя в регионе, является ключевым фактором в вопросах 
определения его стратегии «Взгляд на Восток». Исламская Республика представляется неотъемлемым связуюшим звеном в цюбом регионацьном и интеграционном плане и процессе, если учитывать ее эффективный опыт сотруаничества с Россией в области борьбы с терроризмом, содействия в установлении стабильности в соседних странах, ее национальные и региональные возможности, а также принять во внимание важную роль Ирана в ОЭС и геополитическое положение страны, влияющее на функщионирование транспортного коридора «Север - Юг» . Страна явмяется точкой пересечения кумьтурных, интеммектуальных, институциональных тенденций в трех стратегических регионах БАижнего Востока, Евразии и Восточной Азии. Эти важные коммуникационные особенности, наряну с экономическими, энергетическими возможностями, усилиями в установлении безопасности, могут сыграть важную роль дАя него как ответственного и позитивного игрока в формировании будушей региональной и международной системы.

Опыт, полученный в рамках ирано-российского сотрудничества по вопросам установления безопасности в Сирии, может открыть окно возможностей Аля создания стабильности в Афганистане и странах Центральной Азии. В связи с тем, что войска США уже выведены из Афганистана, а деятельность ИГИА в этой стране может стать причиной сотрудничества межау Россией и Ираном в сфере безопасности, особенно если оно будет подАержано участниками ШОС, это станет значимым фактором предотвращения кризисов и управления ими в указанной сфере. Нестабильный Афганистан и слабые правительства в Центральной Азии в будущем могут стать наиболее уязвимыми территориями как Аля региональной азиатской подсистемы, так и Аля общей системы межАународных отношений [17, с. 30] .

В последние годы Иран активно борется за признание его права на ведение исследований в области мирного атома, установление стабильной и безопасной, свободной от террористической активности зоны на БАижнем Востоке. В связи со схожей активной и конструктивной позиџией России по этим и Аругим вопросам, остро стоящим на межАународной повестке Аня, представляется целесообразным более детально рассмотреть, какой характер носят отношения этих Авух стран. В целях большего понимания стоит обратить внимание на предысторию формирования внешнеполитического курса в России.

После распада Советского Союза во внешней политике Российской Федерации возникли три основных дискурса. Еброатлантический дискурс стал Аоминирующим сразу после распада и продолжался Ао середины 1990-х годов. ЕВразийский дискурс возник в ответ на неудачи предылушего Аискурса и смог сохранить доверие к себе до избрания 
В.В. Путина Президентом РФ. После его прихода к власти нащионалистический дискурс, выраженный в идее «нормальной Великой держаъъ» [18, с. 97], вошел в западные научные исследования о внешней помитике современной России. Сам термин, как представмяется, заимствован у первого министра иностранных дел РФ А.В. Козырева [19] и понимается как комплекс мероприятий и усиций, направленных на отказ от «советского изоляџионизма» в пользу интеграџии России в межАународное сообщество "демократических государств» в качестве полноценной, формирующей повестку Аня участниџы мировых процессов $[20 ; 21$, с. 15$]$.

В.В. Путин всегда подчеркивац, что Россия в прошиом была и в будущем продолжит быть великой державой благодаря ее особым характеристикам [22]. Следуя этому, он стал выстраивать внешнюю политику страны, направленную на взаимодействие с Западом и достижение новых глобальных договоренностей с учетом интересов России, подчеркивая стратегию «нормальной современной великой державы» [20] . Тем временем концепция евразийства, выражавшая стремление поддерживать стабильные отношения как с Востоком, так и с Западом и находить баланс межАу ними, снова ушла на второй план. Как считает Аж. Карами, ярко выраженная направленность России того времени к Западу игнорироваяа значимую часть ее интересов и приоритетов. Аیя создания равновесия следовало также учитывать отношения с восточными странами - Китаем, Японией, Индией и государствами Ближнего Востока [23, с. 65]. В дальнейшем внешнеполитический курс заново был выстроен по принципу «срединного пути».

Появление евразийской концепции вызвало разные точки зрения и подходы как внутри страны, так и за ее переделами. Ряд российских экспертов полагают, что идея евразийства, так же как и чрезмерное тяготение к Востоку, может быть довольно критична Амя российской экономики и даже дмя наџионального суверенитета. К тому же высказывается мнение, что движение в данном направлении может составить серьезную угрозу Амя разложения русской православной цивилизации $[24$, c. 43$]$, но в самом Кремле убежждены в том, что евразийский выбор - это раџиональный путь Аля более эффективного внешнеполитического и экономического курса России. Подобный тезис неоднократно подтвердили различные программные документы развития государства. Например, в действующей Концепции внешней политики Российской Федерации, утвержденной Президентом РФ 30 ноября 2016 г., в разделе «Региональные приоритеты внешней политики Российской Федерации» четко просматривается намерение углубцять и расширять интеграцию межАу государствами Евразии [25]. Такое распредемение

46 Bulletin of the Volga Region Institute of Administration • 2021. Vol. 21. № 6 
приоритетов российский политолог С.А. Караганов объясняет желанием остановить экспансию западных союзов на жизненно важные Амя России территории и уравновесить рост мощи Китая в отношении к Западу [26].

Наиболее ярко концепция евразийства нашиа свое выражение в статье В.В. Путина 2011 г., в то время занимавшего должность председателя кабинета министров, которую многие восприняли как предвыборную программу перед президентскими выборами 2012 г. В.В. Путин продвигает идею создания наднационального объединения - Евразийского союза - на основе существующих интеграционных объединений, «...способного стать одним из полюсов современного мира и при этом играть роль эффективной «связки» межАу Европой и динамичным Азиатско-Тихоокеанским регионом» [27] .

Исследователи также обращают внимание на то, что Российская Федерация современными отечественными политиками воспринимается как яАро интеграции, при этом территория стран СНГ как зона Евразийского союза. К тому же в политическое пространство Евразии включают Китай, Индию, Пакистан, Иран, Турџию и другие государства, которые, в свою очередь, входят и в иные интеграционные объединения, влияющие на расклад сил в регионе. Таким образом, разноскоростная интеграция стран Евразии можкет привести к созданию альянса континентальных держкав как глобальной скрепы Амя сохранения единого пространства и кооперации континентальных стран-цивилизаций [28, с. 179-180].

В российско-иранских отношениях всестороннее развитие сотруАничества нашло закрепление в Конџепџии внешней политики Российской Федерации: «Россия проводит цинию на всестороннее развитие сотрудничества с Исламской Респубцикой Иран, а также добивается последовательной реализации всеобъемлющей договоренности по урегулированию ситуации вокруг иранской ядерной программы на основе резолющии Совета Безопасности ООН 2231 от 20 июля 2015 г., соответствующих решений Совета управцяющих МАГАТЭ и оказывает этому процессу всестороннее содействие» [25] .

Оба государства столкнулись с необходимостью сдерживать США и их союзников, препятствовать распространению влияния стран Запада в регионе. Таким образом, данные устремления явились одним из важных факторов, подталкивающих Тегеран и Москву к участию в одних и тех же региональных проектах государств «Большой Евразии». В целом их взаимодействие в рамках евразийской интеграции способствует реализации разцичных интересов каждого из государств и обеспечивает «макрополезность», создавая почву дия относительного влияния Тегерана в регионе Ближнего Востока и Џентральной Азии.

ОАнако иранский эксперт А. Нури пришел к вывоАу, что, несмот- 
ря на указанные преАпосылки расширения своего влияния, Ирану не удалось продвинуть свои интересы в регионе, особенно по сравнению с соперниками. Москва и Тегеран осознают, что цена индивидуальных действий, направленных на достижкение обозначенных обоюдных цемей высока и что посредством взаимодействия они могут эффективнее следовать своим интересам и устранять угрозы. В связи с этим В.В. Путин подчеркнул участие Ирана в проекте сотрудничества «Большая Евразия», а его поддержка членства Тегерана в ШОС наряду с договоренностями Москвы с Ираном и странами - чиенами ЕЭС Аемонстрируют подхоА, основанный на взаимодействии и взаимном учете интересов [29, с. 245-248]. В сентябре 2021 г. Иран в рамках присоединения к ШОС Аостиг больших успехов. ШОС единогласно приняла ИРИ в качестве полноправного чиена. Это дия Тегерана означает открытие дверей крупных и перспективных рынков в Азии и преодоление экономических санкщий, введенных Западом, особенно США.

Резюмируя изложенное об особенностях построения внешнеполитического курса Исламской Республикой Иран, в частности, предпочтении Востока Западу, можно констатировать, что сегодня выбранная стратегия «ВзгляА на Восток» приобрела четкие контуры и направлена на поиск стратегического партнера в цемях экономического роста и промышиенного развития среди государств восточной цивилизации, к которой Иран относится с позиџии его идентичности, истории и культуры. Ориентация на Восток призвана уравновешивать позищии Ирана по отношению к странам Запада в регионе. За последние два десятияетия Иран несколько раз разочаровался в готовности США и их сатемиитов устанавливать добрые партнерские отношения. Последним ярким примером явилась «ядерная сделка», которая так и не была заключена в соответствии с договоренностями. Конечно, это не означает игнорирования Тегераном Запада. Напротив, Исламская Республика неоднократно декларировала принцип конструктивного взаимодействия с миром. Внешнеполитические усилия Ирана были положительно восприняты основными центрами силы на евразийском континенте - Китайской Народной Республикой, Индией и Российской Федерацией. Россия, в свою очередь, в настоящее время также проводит политику противостояния экспансии Запада и его союзов на территории Евразии, что способствует неизбежному сближению Москвы и Тегерана. Расширяя отношения с Китаем и эффективно содействуя развитию мирной ядерной программы Ирана, Россия в своей восточной стратегии имеет особый взгляд на БАижкний Восток и исламский мир в целом. Это регион, в котором накопилось недовольство Соединенными Штатами Америки и пессимизм по отношению к Западу, что явмяется историческим шансом дмя России использовать эти настроения и вернуть потерянные после распада СССР зоны влияния на 
БАижнем Востоке. Известно, что предпринимаются действенные шаги по укреплению дружкественных отношений с государствами Ближнего Востока, при этом Россия придержиивается концепции многовекторной направменности и держит курс на установление диалога с различными мегитимными противоборствующими силами вне зависимости от их собственных предпочтений во внешнеполитическом курсе. Такой подхоА уже Аает свои плоды - например, признание миротворческой роли Российской Федерации, в частности на БАижнем Востоке.

Иранский «ВзгляА на Восток» и российское евразийство, которые имеют много общего в концептуальном и функциональном плане, возникли по целому ряду причин и в настоящее время выступают в противовес концепциям гегемонии и глобального мидерства США, а также влиянию их стратегических союзников в евразийском регионе. ОАнако отметим, что евразийский подход России включает стремление сбалансировать растущее влияние Пекина в регионе.

Евразия, охватывающая к тому же многие центры добычи углеводородов, в частности Каспий, фокусирует на себе внимание многих великих держав как на Востоке, так и на Западе во главе с Соединенными Штатами Америки. Учитывая, что сегодня форсируется развитие новых транспортных артерий, реализуются такие международные проекты, как коридор «Север - Юг», в обозримом будущем станет возможной транспортировка углеводородов Каспийского бассейна напрямую в Персидский залив. Эти перспективы вызвали желание Пекина расширить свое влияние в регионе. Подобные устремления вызывают в Тегеране и Москве и интерес, и озабоченность. Именно поэтому Иран и Россия фокусируют свое внимание на процессах внутри континента Евразия, что связано с безопасностью и суверенитетом обеих стран. По этой же причине Иран предпринимает необходимые меры дмя развития Аружественных прочных отношений с каждой из ключевых стран - членов ШОС, имеющих право вето в ООН. Таким образом, во внешнеполитическом плане Иран рассчитывает опосредованно получить больший вес на межАународной арене, чтобы усилить свой сдерживающий потенџиал в отношении крупных западных игроков. В то же время Исламская Республика преследует собственные интересы и во внутриполитическом плане - добивается экономического роста и промышленного развития.

\section{Библиографический список}

1. Bayanat dar didar-e mardom-e Azerbayjan-e sharghi / пер. с фарси: Выступление лидера на встрече с жителями Восточного Азербайджана // Официальный сайт великого лидера Исламской революции Ирана (18 февр. 2018 г.). URL: https://farsi. khamenei.ir/speech-content?id $=38975$

2. Sanad-e cheshmandaz-e jomhouri-e eslami-e Iran dar ofogh-e 1404 / пер. с фарси: 
Документ о перспективах 1404 г. ИРИ // Официальный сайт великого лидера Исламской революции Ирана (3 нояб. 2003 г.). URL: https://farsi.khamenei.ir/messagecontent?id=9034

3. Телеобращение по случаю праздника жертвоприношения Ид аль-Адха: Американский народ поставит на колени правящий режим // Официальный сайт великого лидера Исламской революции Ирана (31 июля 2020 г.). URL: https://russian.khamenei. ir/news $/ 4420$

4. Калибаф акцентирует прочность и преемственность стратегических отношений между Ираном и Россией // Русская служба Гостелерадио Ирана (9 февр. 2021 г.). URL: https://parstoday.com/ru/news/russia-i124748

5. Передача послания Путина для Верховного лидера Исламской революции // Русская служба Гостелерадио Ирана (7 марта 2021 г.). URL: https://parstoday.com/ru/ news/iran-i126398

6. Ходаренок M. «Ясный сигнал»: Иран и Россия отрабатывают оборону в Индийском океане // Газета.Ru. 2021. 16 февр. URL: https:/www.gazeta.ru/ army/2021/02/16/13480958.shtml

7. Индия присоединилась к ирано-российским учениям // Русская служба Гостелерадио Ирана (17 февр. 2021 г.). URL: https://parstoday.com/ru/news/iran-i125288

8. Hunter Shireen T. Iran's Foreign Policy in the Post-Soviet Era. California and London: Praeger, 2010.

9. Sariolkalam M. Siasat-e khareji-e jomhouri-e eslami-e Iran: bazbini-e nazari va paradaim-e e’telaaf/ пер. с фарси: Сариолкалам M. Внешняя политика Исламской Республики Иран: теоретический обзор и парадигма коалиции. Тегеран: Центр стратегических исследований Совета по определению целесообразности, 2000.

10. Akhavan Kazemi B., Arghavani F. Naghsh-e hoviat-e dini dar hamgerai-e Iran va Asia-ye markazi. / пер. с фарси: Ахаван Каземи Б., Аргавани Ф. Роль религиозной идентичности в интеграции Ирана и Центральной Азии // Ежеквартальный политический журнал. Осень, 2011. № 3 (41). С. 1-21.

11. Divsaalar $M$. Rouykard-e negah be shargh dar ravaabet-e khareji-e Iran / пер. с фарси: Дивсаалар М. Взгляд на Восток в международных отношениях Ирана // Еженедельник Пегахе Хозе. 2008. № 237. Информационное агентство Фарс (27 окт. 2008 г.). URL: http://fna.ir/diz

12. Karami J. Iran va rusie: Mottahed-e sharghi ya tahdid-e jonoubi? / пер. с фарси: Карами Дж. Иран и Россия: восточный союзник или южная угроза? // Международный ежеквартальный журнал международных отношений. Осень, 2010. № 3 (2). С. 171-199.

13. Saghafi Ameri N., Ahadi A. Iran va siasat-e negah be shargh / пер. с фарси: Сакафи Амери Н., Ахади А. Иран и политика ориентации на Восток. Тегеран: Центр стратегических исследований, 2008.

14. Adami A. Raahbord-e negah be shargh dar siasat-e khareji-e jomhouri-e eslami-e Iran: didgaha, zamineha va forsatha / пер. с фарси: Адами A. Стратегия взгляда на Восток во внешней политике Исламской Республики Иран: мнения, предпосылки и возможности // Ежеквартальный журнал политических исследований. Весна, 2010. № 7 (2). C. $97-126$.

15. Khayyamdar M. Az shoar-e «na sharghi na gharbi»" ta siasat-e «negah be shargh» / пер. с фарси: Хайямдар М. От лозунга «Ни Восток, ни Запад» к политике «Ориента- 
ция на Восток» // BBC News персидская служба (2 июля 2020 г.). URL: https://www. bbc.com/persian/iran-features-53271139

16. Karami J. Siasat-e ourasiai-e Iran, enghelab-e eslami va siasat-e khareji / пер. с фарси: Карами Дж. Евразийская политика Ирана, Исламская революция и внешняя политика // Ежеквартальный журнал внешней политики. 2018. № 4 (32). С. 159-200.

17. Sanaei M., Karami J. Ravand-e chandjanebegaraai-e beinolmelali va raahbord-e sharghi-e Iran / пер. с фарси: Санаи М., Карами Дж. Курс на многовекторность в международных отношениях и взгляд Ирана на Восток // Ежеквартальный журнал внешней политики. Лето, 2019. № 2 (33). С. 25-56.

18. Azizi $H$. Ravaabet-e mantaghei-e fedrasioun-e rusie: avaamel-e tasirgozar va moteghaierha-ye dakhil / пер. с фарси: Азизи X. Региональные отношения Российской Федерации: определяющие факторы и переменные // Ежеквартальный журнал Центральной Азии и Кавказа. 2012. № 76. С. 95-124.

19. Замятин B. Обсуждается концепция внешней политики. Андрей Козырев: Россия должна стать нормальной великой державой // Коммерсантъ: газета. 1992. 28 нояб., № 47. URL: https://www.kommersant.ru/doc/31532

20. Tsygankov A.P. Vladimir Putin's Vision of Russia as a Normal Great Power // PostSoviet Affairs. 2005. April, № 21(2). P. 132-158. URL: https://www.researchgate.net/publication/250171757_Vladimir_Putin's_Vision_of_Russia_as_a_Normal_Great_Power

21. Radin A., Clint C. Russian Views of the International Order. Santa Monica, California: RAND Corporation, 2017.

22. Обращение к гражданам страны при вступлении в должность Президента России // Официальный сайт Президента России (7 мая 2004 г.). URL: http://kremlin. $\mathrm{ru} /$ events/president/transcripts/22452

23. Karami J. Tahavvolat-e siasat-e khareji rusie: hoviat-e dolat va masale-ye gharb / пер. с фарси: Карами Дж. Перемены во внешней политике России: государственная идентичность и проблема Запада. Тегеран: Институт политических и международных исследований, 2005.

24. Королев A.A. Евразийство: от идей к современной практике // Знание. Понимание. Умение. 2015. № 1. С. 38-52.

25. Концепция внешней политики РФ // Официальный сайт МИД РФ (1 дек. 2016 г.). URL: https://www.mid.ru/foreign_policy/official_documents/-/asset_publisher/CptICkB6BZ29/content/id/2542248

26. Караганов C.A. Российская внешняя политика: новый этап? // Российская газета. 2016. 25 мая. URL: https://rg.ru/2016/05/25/specialisty-predstavili-svoe-videnieprioritetov-vneshnej-politiki-rf.html

27. Новый интеграционный проект для Евразии - будущее, которое рождается сегодня // Известия: информационный портал. 20113 окт. URL: https://iz.ru/news/ 502761?page $=2$

28. Яшкова T.A. Евразийская интеграция как приоритетное направление российской внешней политики // Евразийский союз: вопросы международных отношений: научный журнал. 2014. № 1-2. С. 178-181.

29. Nouri A. Iran, Rusie va hamgarai-e ourasiai; manaafe-e mantaghegarai-e faal / пер. с фарси: Нури А. Иран, Россия и евразийская интеграция; интересы активного регионализма // Исследования Центральной Евразии. 2019. № 1 (12). С. 235-252. 